Materiales de Construcción

Vol. 66, Issue 324, October-December 2016, e102

ISSN-L: 0465-2746

http://dx.doi.org/10.3989/mc.2016.10415

\title{
Characterization of the properties of perlite geopolymer pastes
}

\author{
G.M. Tsaousi $\bowtie$, I. Douni, D. Panias \\ National Technical University of Athens (NTUA) (Athens, Greece) \\ $\triangle$ margitsaousi@metal.ntua.gr
}

\author{
Received 20 November 2015 \\ Accepted 19 April 2016 \\ Available on line 13 October 2016
}

\begin{abstract}
This paper deals with the characterization of perlite-based geopolymer pastes, using fine perlite as raw material. The present study examined the effects of the main synthesis parameters such as perlite to activator ratio, $\mathrm{NaOH}$ concentration, the addition of soluble silica to the activator, and curing temperature on the setting time, the stability in an aquatic environment, the viscosity of the paste, and the compressive strength of the solidified geopolymers. The results showed that these inorganic polymer pastes are non-Newtonian shear thinning fluids that achieve low viscosities at high shear stresses. The optimum synthesis conditions for the geopolymer pastes proved to be a) a low initial $\mathrm{NaOH}$ concentration in the alkaline phase $(2-5 \mathrm{M})$ and b) a solid to liquid ratio of $1.2-1.4 \mathrm{~g} / \mathrm{mL}$. If very fast setting is necessary, the pastes should be prepared with a soluble silica-doped alkaline activating phase and cured at high temperatures around $90{ }^{\circ} \mathrm{C}$.
\end{abstract}

KEYWORDS: Perlite; Geopolymer paste; Alkali activation; Characterization

Citation/Citar como: Tsaousi, M.; Douni, I.; Panias, D. (2016) Characterization of the properties of perlite geopolymer pastes. Mater. Construcc. 66 [324], e102. http://dx.doi.org/10.3989/mc.2016.10415.

RESUMEN: Caracterización de las propiedades de pastas geopoliméricas de perlita. El presente trabajo trata de la caracterización de pastas geopoliméricas basadas en perlita utilizando perlita fina como materia prima. Se han examinado los efectos que tienen los principales parámetros de síntesis - tales como la relación perlita/activador, la concentración de $\mathrm{NaOH}$, la adición de sílice soluble al activador y la temperatura de curado- sobre el tiempo de fraguado, la estabilidad en medio acuoso, la viscosidad de la pasta y la resistencia a la compresión de los geopolímeros solidificados. Los resultados han mostrado que estas pastas poliméricas inorgánicas son fluidos no-Newtonianos de viscosidad estructural que alcanzan bajos niveles de viscosidad a alta tensiones de cizalla. Las condiciones óptimas de síntesis para las pastas geopoliméricas resultaron ser a) baja concentración inicial de $\mathrm{NaOH}$ en la fase alcalina $(2-5 \mathrm{M})$ y b) una relación sólido-líquido entre 1,2 y 1,4 g/mL. Si se requiere fraguado muy rápido, se tienen que preparar las pastas con un activador alcalino dopado con sílice soluble y curar a altas temperaturas cercanas a $\operatorname{los} 90^{\circ} \mathrm{C}$.

PALABRAS CLAVE: Perlita; Pasta geopolimérica; Activación alcalina; Caracterización

Copyright: (C) 2016 CSIC. This is an open-access article distributed under the terms of the Creative Commons Attribution License (CC BY) Spain 3.0.

\section{INTRODUCTION}

Geopolymerization is an innovative technology that can utilize solid aluminosilicate raw materials (powders) and alkali metal silicate solutions to produce new materials characterized by three-dimensional polymeric structures called geopolymers or inorganic polymers (1). Extensive research in the field of geopolymeric synthesis in recent decades has proved that geopolymers possess excellent mechanical and physicochemical properties. They exhibit high surface hardness, high 
mechanical strength, fire and chemical resistance, thermal stability, low density, and micro- or nanoporosity (2-9). As a result of these properties, inorganic polymers are considered ideal alternatives for many industrial applications, mainly in the construction sector.

The geopolymerization process is based on an exothermic heterogeneous chemical reaction between a solid aluminosilicate raw material and an alkali metal silicate solution under atmospheric conditions and at temperatures up to $100{ }^{\circ} \mathrm{C}$. The materials synthesized by this reaction present mainly an amorphous or semi-crystalline Si-O-Al and/or Si-O-Si frame. A variety of solid industrial residues or wastes such as fly ash, metallurgical slags, and mine wastes, and industrial minerals such as kaolinite and feldspars (10-19), have been used for the synthesis of geopolymers. Perlite, however, has not been extensively studied as a potential aluminosilicate source for the synthesis of inorganic polymers through geopolymerization. The main reason for this is that perlite has long been considered as an inefficient raw material for geopolymerization that produces final materials lacking the desired mechanical properties. Perlite has been activated with alkaline solutions to produce geopolymer binders or mortars. After casting at $60{ }^{\circ} \mathrm{C}$ the materials produced were found to be porous and fragile (20). In the case of mortars, sodium silicate-activated mixtures slowly reach moderate strengths at room temperature but mixtures activated with sodium hydroxide do not develop the required strength. The mechanical properties have been found to improve with $100^{\circ} \mathrm{C}$ dry curing (21).

Perlite is an amorphous aluminosilicate volcanic glass which, upon rapid controlled heating, expands into a foam material of low bulk density. Perlite deposits are normally exploited by means of lowcost open-pit mining methods followed by in-situ milling and screening. Greece and Turkey are the world's leading perlite producers, with an annual production in 2015 of 700,000 tons and $1,100,000$ tons, respectively (22), while in Europe the annual production of perlite was estimated at about $1,935,000$ tons in 2015 (22)

This paper deals with the characterization of perlite-based geopolymer pastes, using fine perlite as raw material. It studies the effects of the main synthesis parameters - such as perlite-to-activator ratio $(\mathrm{S} / \mathrm{L}), \mathrm{NaOH}$ and soluble silica concentrations in the activator, and curing temperature - on the setting time and rheological properties of the geopolymer pastes synthesized.

\section{EXPERIMENTAL}

\subsection{Materials}

The raw materials used for the synthesis of geopolymer paste were fine perlite, sodium hydroxide, and a sodium silicate solution. The fine perlite originated from Imerys deposits on the Greek island of Milos. Table 1 shows the chemical analysis of this perlite on a dry basis, determined using a Xepos X-ray fluorescence spectrometer and X-LAB software. The main chemical components of the perlite used were found to be silicon, aluminum, sodium, and potassium, while magnesium and calcium were minor constituents. Loss on ignition was determined as the amount of perlite remaining after $1 \mathrm{~h}$ at $1100^{\circ} \mathrm{C}$.

Figure 1 shows the mineralogical analysis of the perlite used, which was determined by X-ray diffraction (XRD) on a Siemens D5000 diffractometer using $\mathrm{Cu} \mathrm{K} \alpha$ radiation $(\lambda=1.5418 \mathrm{~A})$ operating at $40 \mathrm{kV}, 30 \mathrm{~mA}$, at $2 \theta$ range from $2^{\circ}$ to $80^{\circ}$ with a $0.02^{\circ} \mathrm{sec}^{-1}$ step. Fine perlite is an amorphous volcanic aluminosilicate glass that contains some crystalline phases, such as illite, feldspars (albite and anorthite), and quartz (23). Raw perlite is extremely fine, with a mean particle size of $\mathrm{d}_{50}=6.87 \mu \mathrm{m}$ measured on a Malvern laser particle size analyzer. Its skeletal density, measured with a Quantachrome Stereopycnometer, is $2433 \mathrm{~kg} / \mathrm{m}^{3}$. Table 2 shows the surface characteristics, such as BET specific surface area and pore volume, measured by a Quantachrome Nova-1200 Ver 5.01 porosimeter.

The alkaline activator used for the synthesis of the geopolymer pastes was an aqueous sodium hydroxide and sodium silicate solution that was prepared by dissolving sodium hydroxide pellets (Merck Chemicals, $99 \%$ purity) in deionized water and mixing this solution with the appropriate volume of sodium silicate solution (Merck Chemicals, extra purity). The characteristics of the sodium silicate solution used to study the effect of the initial Si concentration in the activating phase were 7.5-8.5\% $\mathrm{Na}_{2} \mathrm{O}, 25.5-28.5 \% \mathrm{SiO}_{2}$, and $1296-1396 \mathrm{~kg} / \mathrm{m}^{3}$ at $20{ }^{\circ} \mathrm{C}$.

\subsection{Paste preparation}

The viscous geopolymer paste was prepared by mixing perlite with the alkaline activating solution using a mechanical stirrer for 5 minutes until a homogeneous mixture was obtained. The resulting paste was molded in appropriate open Teflon

TABLE 1. Chemical analysis of perlite

\begin{tabular}{ccccccccc}
\hline & \multicolumn{1}{c}{ Oxides $(\%)$ w/w } \\
\hline $\mathrm{Na}_{2} \mathrm{O}$ & $\mathrm{MgO}$ & $\mathrm{Al}_{2} \mathrm{O}_{3}$ & $\mathrm{SiO}_{2}$ & $\mathrm{~K}_{2} \mathrm{O}$ & $\mathrm{CaO}$ & $\mathrm{Fe}_{2} \mathrm{O}_{3}$ & LOI & TOTAL \\
3.70 & 1.45 & 13.56 & 67.21 & 4.85 & 1.11 & 2.27 & 5.54 & 99.69 \\
\hline
\end{tabular}




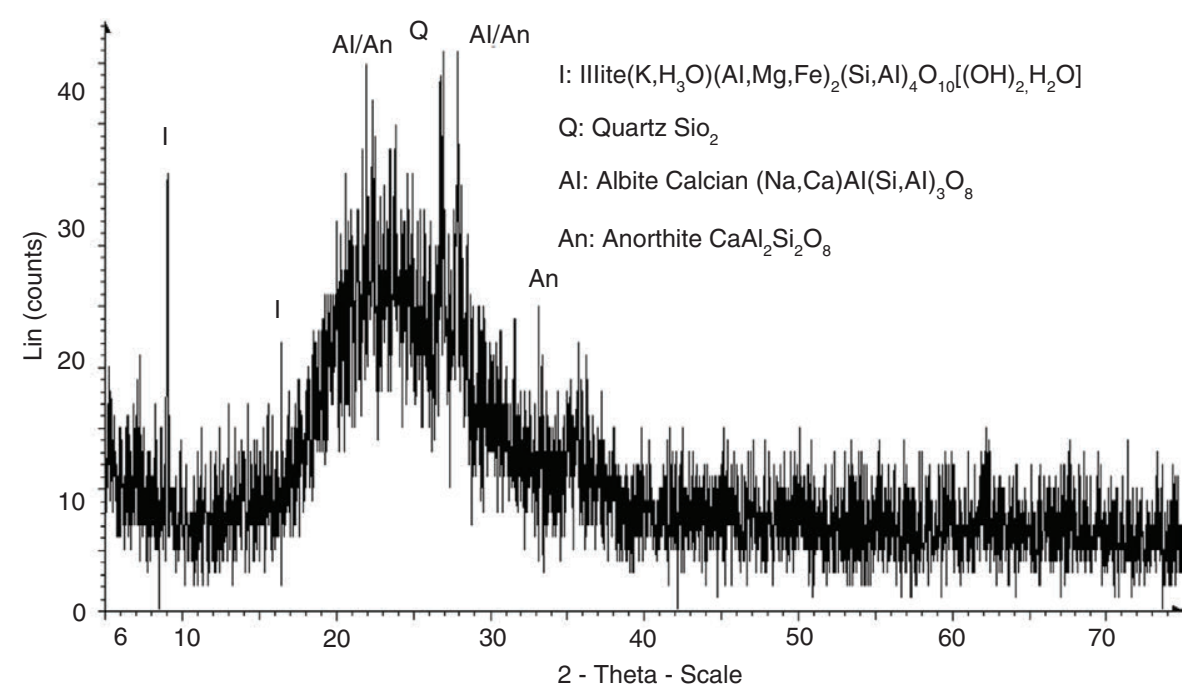

FIgURE 1. X-ray diffractogram of perlite.

TABLE 2. Surface properties of perlite

\begin{tabular}{lc}
\hline Surface characteristics & Value \\
\hline Specific surface $\operatorname{area}\left(\mathrm{m}^{2} / \mathrm{g}\right)$ & 14.48 \\
Total pore volume $\left(\mathrm{cm}^{3} / \mathrm{g}\right)$ & 0.03 \\
Average pore diameter $(\AA)$ & 83.46 \\
All pores diameter $(\AA)$ & $<1060.79$
\end{tabular}

molds ( $5 \mathrm{~cm}$ cubes) and then cured at four different temperatures $\left(50^{\circ} \mathrm{C}, 70{ }^{\circ} \mathrm{C}, 90^{\circ} \mathrm{C}, 100^{\circ} \mathrm{C}\right)$. The maximum linear shrinkage observed in the final materials was $1 \%$. The $\mathrm{NaOH}$ concentration used in the alkaline activating solution ranged from $2 \mathrm{M}$ to $12 \mathrm{M}$, and the solid to liquid ratio examined was $1.2-1.4 \mathrm{~g} /$ $\mathrm{mL}$. The soluble silica concentration used in the activating phase ranged from $0.7 \mathrm{M}$ to $2.7 \mathrm{M}$. After curing, the specimens were demolded and kept in a dry atmosphere.

\subsection{Characterization tests}

The setting time of the geopolymer pastes was measured using a MATEST Vicat apparatus in accordance with EN 196-3:2005.

The viscosity of the geopolymer pastes was measured immediately after their preparation at ambient temperature using a Brookfield Viscometer LV+.

The hydrolytic stability of the solidified geopolymer pastes was determined by means of a dissolution test in deionized water. An aliquot of $2 \mathrm{~g}$ of solidified sample was totally immersed in $100 \mathrm{~mL}$ of deionized water and left in contact for $24 \mathrm{~h}$ at ambient temperature. Then, the solution was filtered and analyzed for its silicon and aluminum content using an inductively coupled plasma mass spectrometer.
The remaining piece of the geopolymer was dried for $24 \mathrm{~h}$ at $100^{\circ} \mathrm{C}$ and then weighed to determine the $\%$ weight loss (WL).

The dissolution of silicon from the perlite in the sodium hydroxide solutions was studied in a $500 \mathrm{~mL}$ mechanically stirred spherical glass reactor equipped with a thermostatically controlled heating mantle connected to a mercury contact thermometer, a mechanical stirrer with speed controller, and a glass condenser. The dissolution tests were performed at $30{ }^{\circ} \mathrm{C}$ with a pulp density of $16 \mathrm{~g} / \mathrm{L}$, $\mathrm{NaOH}$ concentrations of $1-10 \mathrm{M}$, and $24 \mathrm{~h}$ retention time. At the end of each test the suspension was filtered and the filtrate was further analyzed for its silicon content using an inductively coupled plasma mass spectrometer.

The compressive strength of the $5 \mathrm{~cm}$ cubic geopolymer specimens was measured using an Advantest 9 apparatus in accordance with EN772-1. After the preparation of the paste, the slurry was molded into appropriate molds and cured in two phases $\left(48 \mathrm{~h}\right.$ at $70{ }^{\circ} \mathrm{C}$ and $96 \mathrm{~h}$ at $55{ }^{\circ} \mathrm{C}$ ). The solidified geopolymers remained at ambient temperature for 23 more days, after which their compressive strength was immediately measured.

\section{RESULTS AND DISCUSSION}

\subsection{Effect of $\mathrm{NaOH}$ concentration on geopolymer paste properties}

The effect of the initial $\mathrm{NaOH}$ concentration in the activating phase on the properties of the geopolymer pastes was studied for the range of $2-12 \mathrm{M}$. The activator consisted of a pure $\mathrm{NaOH}$ solution without the addition of soluble silica in the form of 
a sodium silicate solution. The solid to liquid ratio was kept constant at $1.2 \mathrm{~g} / \mathrm{mL}$ and the pastes were cured at $50{ }^{\circ} \mathrm{C}, 70{ }^{\circ} \mathrm{C}, 90^{\circ} \mathrm{C}$, and $100^{\circ} \mathrm{C}$. The results are shown in Figure 2, where the setting time of the geopolymer pastes synthesized at different temperatures is plotted against the initial concentration of the $\mathrm{NaOH}$ solution.

The results showed a strong trend towards increase in setting time as a function of $\mathrm{NaOH}$ concentration. At $50{ }^{\circ} \mathrm{C}$, as the $\mathrm{NaOH}$ concentration rose from $2 \mathrm{M}$ to $6 \mathrm{M}$, the setting time increased almost six-fold from 20 to 120 hours. For $\mathrm{NaOH}$ concentrations over $6 \mathrm{M}$, the setting time at this temperature was invariable. At $70{ }^{\circ} \mathrm{C}$, the setting time was generally shorter than at $50{ }^{\circ} \mathrm{C}$. It was invariable in the $2-5 \mathrm{M} \mathrm{NaOH}$ concentration range; then, when the $\mathrm{NaOH}$ concentration exceeded $5 \mathrm{M}$, the setting process slowed considerably, only to reach another plateau for $\mathrm{NaOH}$ concentrations over $8 \mathrm{M}$. The setting of the

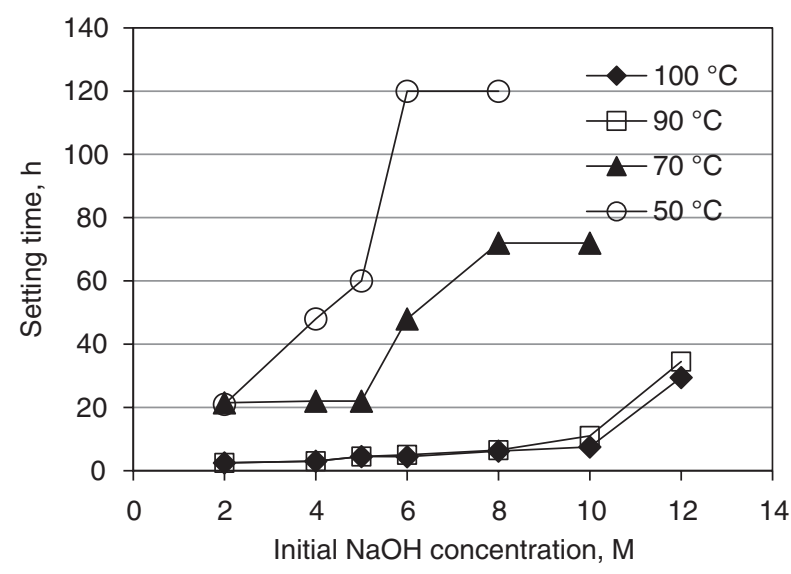

FIGURE 2. Setting time of geopolymer pastes as a function of initial $\mathrm{NaOH}$ concentration in the activator.

(a)

Initial $\mathrm{NaOH}$ concentration, $\mathrm{M}$

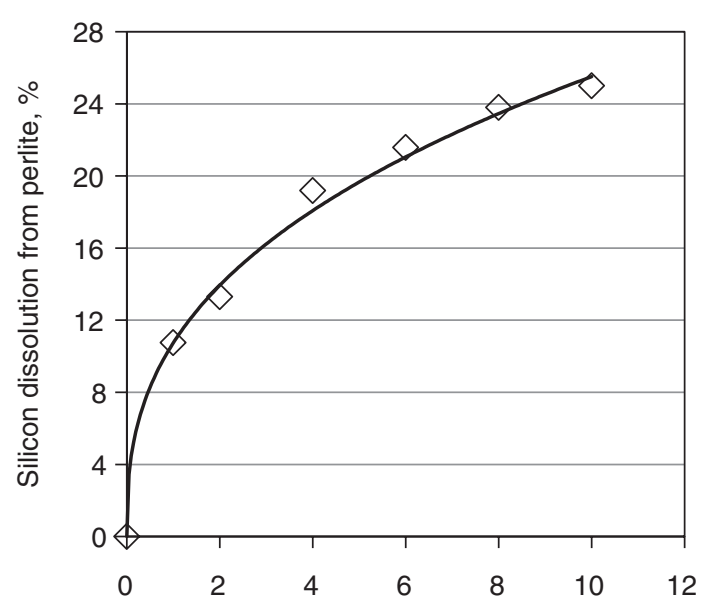

geopolymer pastes was much faster at $90{ }^{\circ} \mathrm{C}$ and $100^{\circ} \mathrm{C}$.

The results revealed that the perlite geopolymer pastes solidified faster under lower $\mathrm{NaOH}$ concentrations in the alkaline activating phase as well as at higher curing temperatures. The former of the above observations would seem to run counter to the common perception that geopolymerization technology is most effective at high $\mathrm{NaOH}$ concentrations $(16,24,25)$. As a matter of fact, as seen in Figure 3a, Si dissolution from perlite after 24 hours retention time at $30{ }^{\circ} \mathrm{C}$ did indeed increase as the initial $\mathrm{NaOH}$ concentration increased, but a tenfold increase in the $\mathrm{NaOH}$ concentration (from $1 \mathrm{M}$ to $10 \mathrm{M}$ ) caused only a 2.5 -fold increase in the silicon dissolution (from $10 \%$ to $25 \%$ ) leaving, according to the dissolution reaction [eq.1], a substantial excess amount of free $\mathrm{NaOH}$ and establishing lower $\mathrm{SiO}_{2} / \mathrm{Na}_{2} \mathrm{O}$ mass ratios in the aqueous phase. The lower $\mathrm{SiO}_{2} / \mathrm{Na}_{2} \mathrm{O}$ mass ratios favor the formation of monomer and oligomer Si species (Fig. 3b) (26-28) and therefore inhibit the polycondensation phenomena, slowing the setting time of perlite geopolymer pastes (27). Besides, the lability of geopolymer gel synthesized with low $\mathrm{SiO}_{2} / \mathrm{Na}_{2} \mathrm{O}$ ratios in the activating solution will be much greater than that of specimens with higher $\mathrm{SiO}_{2} / \mathrm{Na}_{2} \mathrm{O}$ ratios (28).

$$
\mathrm{SiO}_{2}+\mathrm{NaOH}+\mathrm{H}_{2} \mathrm{O} \rightarrow \mathrm{SiO}(\mathrm{OH})_{3}^{-}+\mathrm{Na}^{+}
$$

The compressive strength of the cubic geopolymer specimens in relation to the initial sodium concentration in the activation solution is presented in Figure 4. In this experimental series, the concentration of $\mathrm{NaOH}$ varied between $2 \mathrm{M}$ and $6 \mathrm{M}$, and the solid to liquid ratio was kept constant at $1.2 \mathrm{~g} / \mathrm{mL}$. The formulation using $4 \mathrm{M}$ of activator

(b)

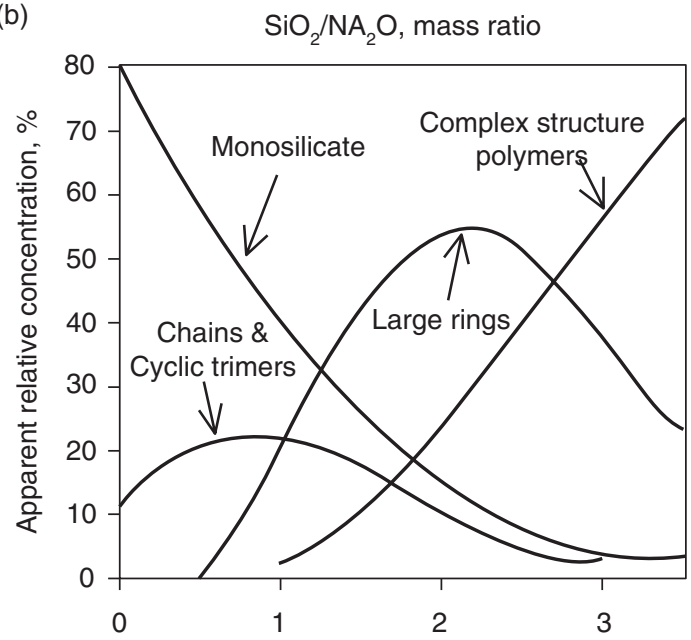

Figure 3. (a) Silicon dissolution from perlite in several $\mathrm{NaOH}$ solutions at $30{ }^{\circ} \mathrm{C}, 24 \mathrm{~h}$ and pulp density $16 \mathrm{~g} / \mathrm{L}$ (b) Qualitative interpretation of soluble silicate species equilibria in $1 \mathrm{~m}$ aqueous silicate solution. 


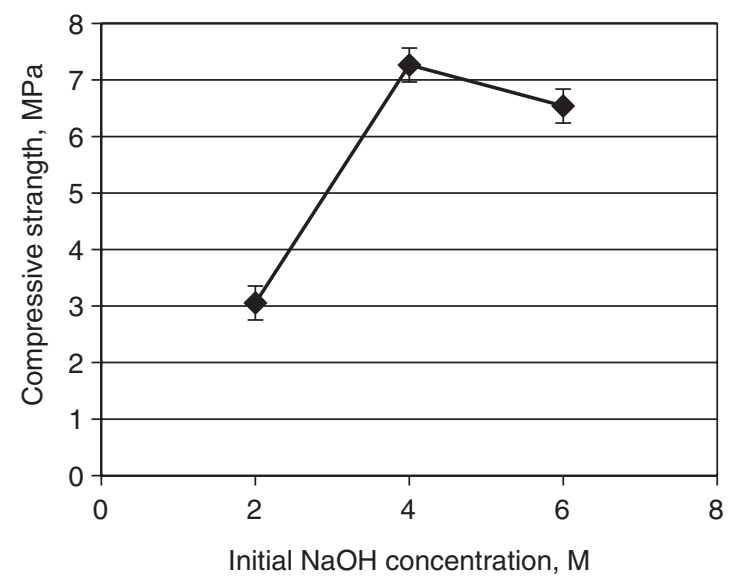

Figure 4. Perlite paste compressive strength versus initial $\mathrm{NaOH}$ concentration with standard deviation $0.32 \mathrm{MPa}$ for $2 \mathrm{M}, 0.25 \mathrm{MPa}$ for $4 \mathrm{M}$, and $0.28 \mathrm{MPa}$ for $6 \mathrm{M}$. Error bars indicate the average deviation from the mean over the three samples measured.

was the one that resulted in higher compressive strength. Further increases of $\mathrm{NaOH}$ reduced the compressive strength of the synthesized geopolymers: the number of free alkalis was so large that they inhibited the raw material's reaction, inducing a severe degradation of the geopolymeric matrix (29). In addition, the species equilibrium at high alkaline conditions shifts towards mononuclear species formation, slowing the process of polycondensation and reducing its effectiveness as measured by the compressive strength of the geopolymeric materials (16).

The inefficient geopolymerization of the perlite pastes at high $\mathrm{NaOH}$ concentrations in the activating phase led to structures with limited hydrolytic stability, as seen in Table 3. The results showed that the lowest \% weight loss and $\mathrm{Al}$ and Si concentrations in the immersion solution of the hydrolytic test were observed for the material synthesized with $2 \mathrm{M}$ $\mathrm{NaOH}$ solution; these specimens maintained their structural integrity after immersion in the deionized water (29). The specimens synthesized at $6 \mathrm{M}$ and $10 \mathrm{M} \mathrm{NaOH}$ concentrations in the activating phase, on the other hand, were largely destroyed, losing $58.05 \%$ and $64.14 \%$ of their initial weight, respectively, and liberating significant amounts of Si and $\mathrm{Al}$ into the immersion solution. The hydrolytic stability of the geopolymers is reflected in the stability of the aluminosilicate gel in aquatic conditions. Contact with water causes hydrolysis of Si-O-Si bonds in the gel and release of Si followed by partial degradation of the structure (30). The presence of $\mathrm{Al}$ ions in the leachate indicates a certain degree of dealumination due to the degradation of Al-O-Si bonds (31).

Measurements of the paste viscosity offer further evidence of the efficient geopolymerization of perlite under the lowest studied initial $\mathrm{NaOH}$ concentration in the activating phase. This can be seen in Figure 5,
TABLE 3. Hydrolytic stability test results for geopolymeric specimens synthesized with different initial $\mathrm{NaOH}$ concentrations at a solid to liquid ratio of $1.2 \mathrm{~g} / \mathrm{mL}$ and cured at $90^{\circ} \mathrm{C}$ for 24 hours

\begin{tabular}{lrcc}
\hline [NaOH], $\mathbf{M}$ & \% WL & Al $(\mathbf{p p m})$ & $\mathbf{S i}(\mathbf{p p m})$ \\
\hline 2 & 9.14 & $<1.3$ & 42.6 \\
6 & 58.05 & 4.1 & 799 \\
10 & 64.14 & 7.6 & 1070 \\
\hline
\end{tabular}

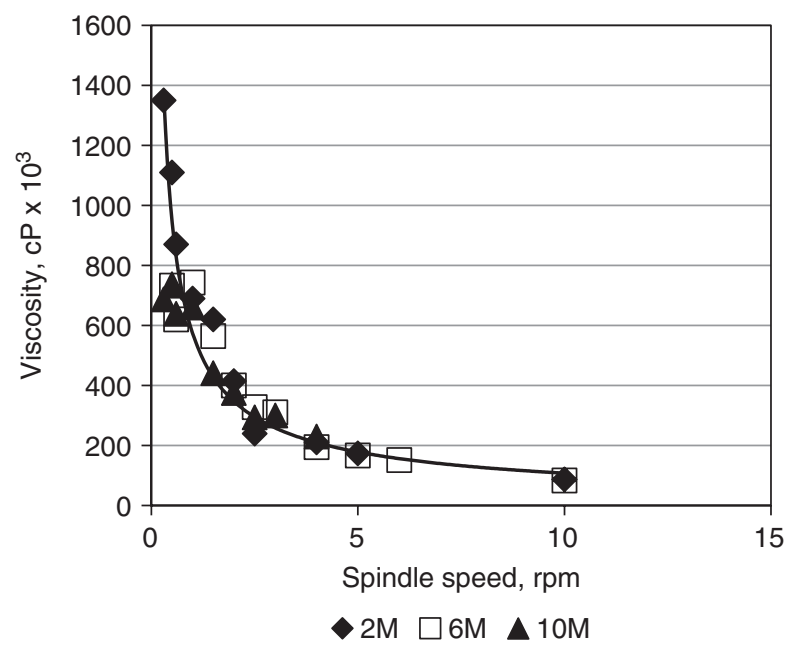

FIgURE 5. Perlite paste viscosity versus $\mathrm{NaOH}$ concentration and viscometer spindle speed at ambient temperature.

which shows the effect of $\mathrm{NaOH}$ concentration on the viscosity of the perlite pastes synthesized. Perlite pastes are non-Newtonian shear thinning fluids that achieve very low viscosities at high shear stresses. No significant effect of $\mathrm{NaOH}$ concentration on viscosity was revealed, indicating that the early viscosity is more related to the large amount of suspended perlite particles in the paste (increased solid to liquid ratio) than to the physical properties of the geopolymer paste. The viscosity measurements are not related to the geopolymer paste itself, because the geopolymerization process has not been completed. An exception can be found in the high viscosity values observed from 800,000 to $1,400,000$ centipoise measured at spindle speeds lower than $1 \mathrm{rpm}$ for the paste synthesized using a $2 \mathrm{M} \mathrm{NaOH}$ solution as activator. This observation proves once more that there is faster polymerization and therefore solidification at $2 \mathrm{M} \mathrm{NaOH}$, indicating that the polycondensation phenomena in the perlite pastes are optimized under low $\mathrm{NaOH}$ concentration.

\subsection{Effect of solid to liquid ratio}

The effect on setting time of the solid to liquid (S/L) ratio used for the preparation of the perlite geopolymer pastes was investigated in the limited range of 1.2 to $1.4 \mathrm{~g} / \mathrm{mL}$, due to the very bad workability 
of pastes at higher $\mathrm{S} / \mathrm{L}$ values. The $\mathrm{NaOH}$ concentration in the activating phase was kept constant at $2 \mathrm{M}$, and the pastes were cured at temperatures ranging from $50^{\circ} \mathrm{C}$ to $100^{\circ} \mathrm{C}$. The results are shown in Figure 6, where the setting time is plotted against the $\mathrm{S} / \mathrm{L}$ ratio. The results showed that the $\mathrm{S} / \mathrm{L}$ ratio did not affect the setting time of the paste at a constant curing temperature. Moreover, the setting of pastes in the temperature range of $50-70{ }^{\circ} \mathrm{C}$ was very slow, and was not completed until after 21-24 hours, even when the S/L ratio was at its highest value of $1.4 \mathrm{~g} / \mathrm{mL}$. On the other hand, at the highest studied curing temperatures of $90-100{ }^{\circ} \mathrm{C}$, the setting time was almost seven to eight times faster, at only $2.5-3$ hours.

Tests were also performed at a low $\mathrm{S} / \mathrm{L}$ ratio of $1.2 \mathrm{~g} / \mathrm{mL}$ and high $\mathrm{S} / \mathrm{L}$ ratio of $1.4 \mathrm{~g} / \mathrm{mL}$ using activating solutions with $\mathrm{NaOH}$ concentrations ranging from $2 \mathrm{M}$ to $10 \mathrm{M}$. The results presented in Figure 7 showed that for both $\mathrm{S} / \mathrm{L}$ ratios, the increase in $\mathrm{NaOH}$ concentration caused an increase in setting time, as was to be expected. The new observation was that the pastes with the higher $\mathrm{S} / \mathrm{L}$ ratio solidified faster under the same $\mathrm{NaOH}$ concentration in the activating phase. This was attributed to the fact that an increased $\mathrm{S} / \mathrm{L}$ ratio, which means there is a higher ratio of perlite per volume of the activating solution, can cause an increase in the concentration of silicon and aluminum precursors in the aqueous phase of geopolymerization (provided that perlite is the only source of soluble silicon and aluminum in the system), which in turn accelerates the polycondensation phenomena and therefore reduces the setting time of the pastes (32). Besides, when a low S/L ratio was employed, there was more fluid medium in the mix, limiting the possibility of contact between

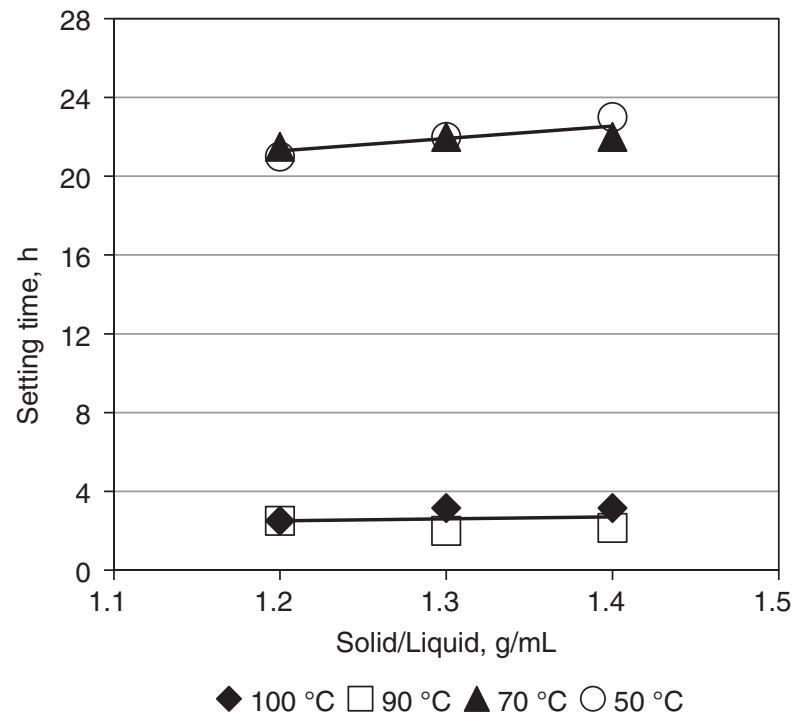

Figure 6. Setting time versus solid to liquid ratio at different curing temperatures. $([\mathrm{NaOH}]: 2 \mathrm{M})$ the activating solution and the solid materials. In contrast, it is believed that when a higher $\mathrm{S} / \mathrm{L}$ ratio was used, the contact between the reacting materials was improved and the geopolymerization mechanism was accelerated $(33,34)$.

\subsection{Effect of initial $\mathrm{SiO}_{2}$ content}

The effect of the initial soluble silica concentration in the activating phase on the setting time of the perlite geopolymer pastes synthesized in this study was determined for the range of $0-2.8 \mathrm{M} \mathrm{SiO}_{2}$. Soluble silica was added in the form of sodium silicate solution while the $\mathrm{NaOH}$ concentration of the activator was kept constant at $2 \mathrm{M}$, which was the optimum value obtained from the previous experimental series.

As shown in Figure 8, for the curing temperatures studied, the setting time of the pastes decreased as the silicon content in the aqueous phase increased (35). Soluble silicate is an essential factor of geopolymerization process, as it provides the aqueous phase of the geopolymeric system with soluble silicate species, which are necessary for the initiation of oligomers formation and thus the polycondensation process $(16,36-39)$. At each curing temperature, an increase in the initial $\mathrm{SiO}_{2}$ concentration in the aqueous phase under constant $\mathrm{NaOH}$ concentration resulted in an increase in the $\mathrm{SiO}_{2} / \mathrm{Na}_{2} \mathrm{O}$ mass ratio at the early stages of the geopolymerization process, therefore speeding up the setting process. As can also be seen in Figure 8, the setting time of the perlite geopolymer pastes converged towards the same value as the $\mathrm{SiO}_{2}$ concentration in the aqueous phase increased, independently of the curing temperature. The convergence slope was substantially

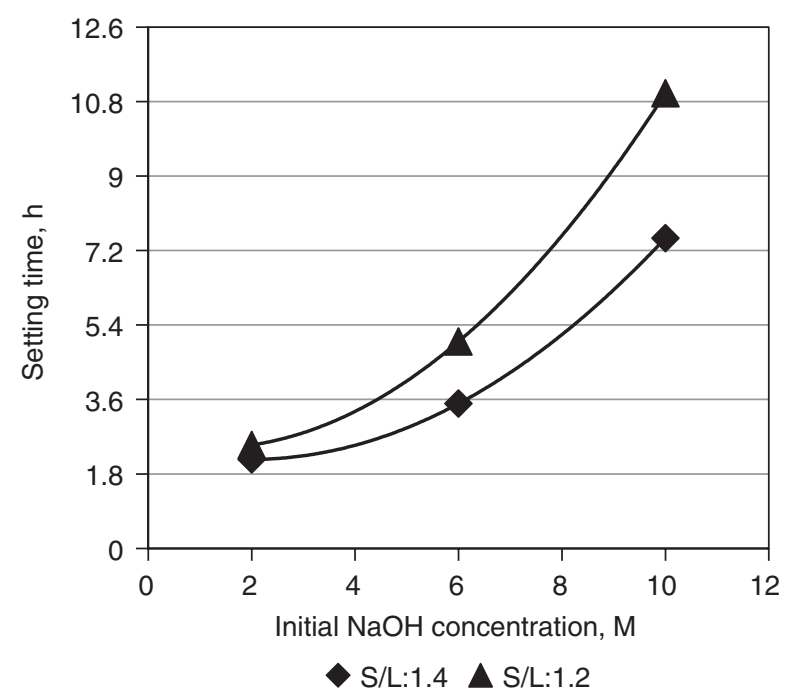

FIGURE 7. Setting time versus $[\mathrm{NaOH}]$ at solid to liquid ratio 1.2 and $1.4 \mathrm{~g} / \mathrm{mL}$. (Curing temperature $90^{\circ} \mathrm{C}$ ) 


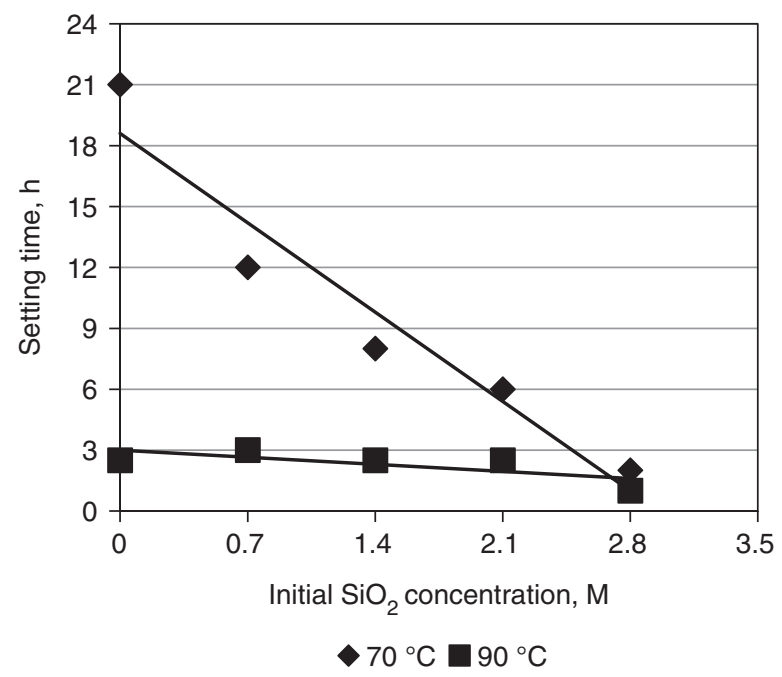

Figure 8. Setting time versus initial $\mathrm{SiO}_{2}$ concentration in activating solution at different curing temperatures $([\mathrm{NaOH}]=2 \mathrm{M}, \mathrm{S} / \mathrm{L}$ ratio $=1.2 \mathrm{~g} / \mathrm{mL})$.

steeper at lower temperatures, indicating that the effect of doping with soluble silica is more significant at lower curing temperatures. This is attributed to the slow and small rate of perlite dissolution in an alkaline environment, as seen in Figure 3a, which makes the $\mathrm{SiO}_{2} / \mathrm{Na}_{2} \mathrm{O}$ mass ratio in the aqueous phase of geopolymerization increase slowly, rendering doping with soluble silica a necessary procedure to speed up the setting of the paste. The temperature increase positively affects the dissolution rate, speeding the increase in the $\mathrm{SiO}_{2} / \mathrm{Na}_{2} \mathrm{O}$ mass ratio under the same conditions and thus smoothing the effect of soluble silica doping on setting time.

\section{CONCLUSIONS}

- This work studied the geopolymerization of fine perlite. Due to the limited dissolution of perlite in sodium hydroxide solutions, perlite geopolymer pastes solidify faster when the sodium hydroxide concentration in the alkaline activating phase is around $2 \mathrm{M}$.

- An increase in $\mathrm{NaOH}$ concentration slows the setting time of the geopolymer pastes. An increase in curing temperature from $50{ }^{\circ} \mathrm{C}$ to $90{ }^{\circ} \mathrm{C}$ has a positive effect on setting time, speeding the solidification process.

- Doping the initial activating phase with soluble silica substantially shortens the setting time of perlite pastes, which converges towards the low value of $1-2 \mathrm{~h}$ as the initial $\mathrm{SiO}_{2}$ concentration of the activating solution approaches $1.7 \mathrm{M}$. The $\mathrm{S} / \mathrm{L}$ ratio has no significant effect on setting time.

- Perlite pastes are non-Newtonian shear thinning fluids that achieve very low viscosities at high shear stresses. The measured viscosities ranged from 100,000 to $1,400,000$ centipoises. There is no significant effect of the initial $\mathrm{NaOH}$ concentration in the activating phase on the paste viscosity.

- The formulation with $4 \mathrm{M}$ of activator produced the geopolymer with the highest compressive strength.

- The optimum synthesis conditions for perlite geopolymer pastes have two typical characteristics: a) a low initial $\mathrm{NaOH}$ concentration in the alkaline activating phase (2-5 M) and b) an S/L ratio of $1.2-1.4 \mathrm{~g} / \mathrm{mL}$. In practical cases where very fast setting is necessary, the pastes should be prepared with a soluble silica-doped alkaline activating phase and cured at high temperatures around $90^{\circ} \mathrm{C}$.

\section{REFERENCES}

1. Davidovits, J. (2005) Geopolymer chemistry and sustainable development. In: Proceedings of the World Congress Geopolymer, Saint-Quentin, France, 9-15.

2. Barbosa, V.F.F.; MacKenzie, K.J.D. (2003) Thermal behavior of inorganic geopolymers and composites derived from sodium polysialate. Mater. Res. Bull. 38 [2], 319-331. http:// dx.doi.org/10.1016/S0025-5408(02)01022-X.

3. Davidovits, J. (1994) Properties of geopolymer cements, In: Proceedings of the first international conference on alkaline cements and concretes, Kiev, Ukraine, 131-149.

4. Swanepoel, J.C.; Strydom, C.A. (2002) Utilization of fly ash in a geopolymeric material. Appl. Geochem. 17 [8], 11431148. http://dx.doi.org/10.1016/S0883-2927(02)00005-7.

5. Nicholson, C.; Fletcher, R.; Miller, N.; Stirling, C.; Morris, J.; Hodges, S.; MacKenzie, K.; Schmücker, M. (2005) Building Innovation through Geopolymer Technology. Chemistry in New Zealand, 69, 10-12.

6. Ryu, G.S.; Lee Y.B.; Koh, K.T.; Chung, Y.S. (2013) The mechanical properties of fly ash-based geopolymer concrete with alkaline activators. Constr. Build. Mater. 47, 409418. http://dx.doi.org/10.1016/j.conbuildmat.2013.05.069.

7. Vaou, V.; Panias, D. (2010) Thermal insulating foamy geopolymers from perlite. Miner. Eng. 23 [14], 1146-1151. http://dx.doi.org/10.1016/j.mineng.2010.07.015

8. Sakkas, K.; Nomikos, P.; Sofianos, A.; Panias, D. (2014a) Sodium-based fire resistant geopolymer for passive fire protection. Fire Mater. 39 [3], 259-270. http://dx.doi.org/10.1002/ fam.2244.

9. Sakkas, K.; Panias, D.; Nomikos, P.; Sofianos, A. (2014b) Potassium based geopolymer for passive fire protection of concrete tunnels linings. Tunnelling Underground Space Technol. 43, 148-156.

10. Barbosa, V.F.F.; MacKenzie, K.J.D.;Thaumatutgo, C. (2000) Synthesis and characterization of materials based on inorganic polymers of alumina and silica: sodium polysialate polymers. Int. J. Inorg. Mater. 2 [4], 309-317. http:// dx.doi.org/10.1016/S1466-6049(00)00041-6.

11. Xu, H.; Van Deventer, J.S.J. (2000) The geopolymerization of alumino-silicate minerals. Inter. J. Miner. Process. 59 [3], 247-266. http://dx.doi.org/10.1016/S0301-7516(99)00074-5.

12. Palomo, A.; Grutzeck, M.W.; Blanco, M.T. (1999) Alkali activated fly ashes-a cement for the future. Cem. Concr. Res. 29 [8], 1323-1329. http://dx.doi.org/10.1016/S0008-8846(98)00243-9.

13. Palomo, A.; Krivenko, P.; Garcia-Lodeiro, I.; Kavalerova, E.; Maltseva, O.; Fernández-Jiménez, A. (2014) A review on alkaline activation: new analytical perspectives. Mater. Construcc. 64 [315], e022. http://dx.doi.org/10.3989/mc.2014.00314.

14. Cheng, T.W.; Chiu, J.P. (2003) Fire resistant Geopolymer produced by granulated blast furnace slag. Miner. Eng. 16 [3], 205-210. http://dx.doi.org/10.1016/S0892-6875(03)00008-6. 
15. Cundi, W.; Hirano, Y.; Terai, T.; Vallepu, R.; Mikuni, A.; Ikeda, K. (2005) Preparation of geopolymeric monoliths from red mu-PFBC ash fillers at ambient temperature, In: Proccedings of the World Congress Geopolymer, Saint Quentin, France, 85-87.

16. Panias, D.; Giannopoulou, I.; Perraki, T. (2007) Effect of synthesis parameters on the mechanical properties of fly ash-based geopolymers. Colloids Surf., A. 301 [1-3], 246254. http://dx.doi.org/10.1016/j.colsurfa.2006.12.064.

17. Maragos, I.; Giannopoulou, I.; Panias, D. (2008) Synthesis of ferronickel slag-based geopolymers. Miner. Eng. 22 [2], 196-203. http://dx.doi.org/10.1016/j.mineng.2008.07.003.

18. Pontikes, Y.; Machiels, L.; Onisei, S.; Pandelaers, L.; Geysen, D.; Jones, P. T.; Blanpain, B. (2013) Slags with a high Al and Fe content as precursors for inorganic polymers. Appl. Clay. Sci. 73, 93-102. http://dx.doi.org/10.1016/j.clay.2012.09.020.

19. Komnitsas, K.; Zaharaki, D.; Perdikatsis, V. (2009) Effect of synthesis parameters on the compressive strength of low-calcium ferronickel slag inorganic polymers. J. Hazard. Mater. 161 [2-3], 760-768. http://dx.doi.org/10.1016/j. jhazmat.2008.04.055

20. Erdogan, S. (2014) Properties of Ground Perlite Geopolymer Mortars. J. Mater. Civ. Eng. 27 [7], http:// dx.doi.org/10.1061/(ASCE)MT.1943-5533.0001172.

21. Vance, E. R.; Perera, D. S.; Imperia, P.; Cassidy, D. J.; Davis, J.; Gourley, J. T. (2009) Perlite waste as a precursor for geopolymer formation. J. Aust. Ceram. Soc. 45 [1], 44 49. http://apo.ansto.gov.au/dspace/handle/10238/3130.

22. U.S. Geological Survey, Mineral Commodity Summaries, January 2016

23. Kaufhold, S.; Reese, A.; Schwiebacher,W.; Dohrmann, R.; Grathoff, G.H.; Warr, L.N.; Halisch, M.; Müller, C.; SchwarzSchampera, U.; Ufer Kaufhold, K et al. (2014) Porosity and distribution of water in perlite from the island of Milos, Greece. Springer Plus 3:598, http://www.springerplus.com/ content/3/1/598, http://dx.doi.org/10.1186/2193-1801-3-598.

24. Rattanasak, U and Chindaprasirt, P. (2009) Influence of $\mathrm{NaOH}$ solution on the synthesis of fly ash geopolymer. Miner. Eng. 22 [12], 1073-1078. http://dx.doi.org/10.1016/j. mineng 2009.03.022.

25. Panagiotopoulou, Ch.; Kontori, E.; Perraki, Th.; Kakali, G. (2007) Dissolution of aluminosilicate minerals and byproducts in alkaline media. J. Mater. Sci. 42 [9], 2967-2973. http://dx.doi.org/10.1007/s10853-006-0531-8

26. PQ Corporation Industrial Chemical Division-National Silicates, Fundamentals of Silicate Chemistry. Available at: http://www.pqcorp.com/corporate/aboutpq.asp (06/04/2006).

27. Falcone, J.S. (1982) Soluble Silicates, Edited by J.S Falcone, Jr, Published Washington, D.C.194: American Chemical Society, (1982).

28. Duxson, P.; Provis, J.; Lukey, G.; Mallicoat, S.; Kriven, W.; Van Deventer, J. (2005) Understanding the relationship between geopolymer composition, microstructure and mechanical properties. Colloids Surf., A. 269 [1], 47-58. http://dx.doi.org/10.1016/j.colsurfa.2005.06.060.

29. Taxiarchou, M.; Panias, D.; Panagiotopoulou, Ch.; Karalis, Th.; Dedeloudis, A. (2013) Study on the suitability of volcanic amorphous aluminosilicate rocks (perlite) for the synthesis of Geopolymer-based concrete. ASTM International Symposium on Geopolymer Binder Systems, 1566, 34-53, http://dx.doi.org/10.1520/STP156620120077.

30. Skorina, T.; Tikhomirova I. (2012) Alkali silicate binders: Effect of $\mathrm{SiO}_{2} / \mathrm{Na}_{2} \mathrm{O}$ ratio and alkali metal ion type on the structure and mechanical properties. J. Mater. Sci.47 [12], 5050-5059. http://dx.doi.org/10.1007/s10853-012-6382-6.

31. Nicolic, I.; Durovic, D.; Zejak, R.; Karanovic, L.; Tadic, M.; Blecic, C., Radmilovic, V. (2013) Compressive strength and hydrolytic stability of fly ash based geopolymers. $J$. Ser. Chem. Soc. 78 [6], 851-863. http://dx.doi.org/10.2298/ JSC121024001N

32. Panias, D.; Giannopoulou, I. (2007) The geopolymerization technology for the utilization of mining and metallurgical solid wastes. In: Proceedings of European Metallurgical Conference, Dusseldorf, Germany, 625-640. EMC 2007.

33. Davidovits, J. (2008) Geopolymer chemistry and applications, $2^{\text {nd }}$ edn, Publisher: Institut Geopolymere, Saint Quentin, France, Chap. 26, 547-574.

34. Heah, C.; Kamarudin, H.; Mustafa Al Bakri, A.; Bnhussain, M.; Luqman, M.; Khairul, Nizar, I.; Ruzaidi, C.; Liew, Y. (2012) Study of solid-to-liquid and alkaline activator ratios on kaolin based geopolymers. Const. Build. Mater. 35, 912-922. http://dx.doi.org/10.1016/j. conbuildmat.2012.04.102.

35. Chindaprasirt, P.; De Silva , P.; Sagoe-Crentsil, K.; Hanjitsuwan, S. (2012) Effect of $\mathrm{SiO}_{2}$ and $\mathrm{Al}_{2} \mathrm{O}_{3}$ on the setting and hardening of high calcium fly ash-based geopolymer systems. J. Mater. Sci. 47 [12] , 4876-4883. http:// dx.doi.org/10.1007/s10853-012-6353-y.

36. Gao, K.; Lin, K.L.; Wang, D.Y.; Hwang, C.L.; Shiu, H.S.; Chang, Y.M. ;Cheng, T.W. (2013) Effects $\mathrm{SiO}_{2} / \mathrm{Na}_{2} \mathrm{O}$ molar ratio on mechanical properties and the microstructure of nano- $\mathrm{SiO}_{2}$ metakaolin-based geopolymers. Constr. Build. Mater. 53, 503-510. http://dx.doi.org/10.1016/j. conbuildmat.2013.12.003.

37. Zuda, L.; Pavlik, Z.; Rovnanikova, P.; Bayer, P.; Cerny, R. (2006) Properties of Alkali Activated Aluminosilicate Material after Thermal Load. Int. J. Thermophys. 27 [4], 1250-1263. http://dx.doi.org/10.1007/s10765-006-0077-7.

38. Lee, W.K.W. ; Van Deventer, J. S. J. (2002) Structural reorganization of class $\mathrm{F}$ fly ash in alkaline silicate solutions. Colloids Surf., A. 211 [1], 49-66. http://dx.doi.org/10.1016/ S0927-7757(02)00237-6.

39. Xu, H.; Van Deventer, J.S.J. (2003) The effect of alkali metals on the formation of geopolymeric gels from alkalifeldspars. Colloids Surf., A. 216 [1], 27-44. http://dx.doi. org/10.1016/S0927-7757(02)00499-5. 